\title{
Enzymatic degradation of isolated plant cuticles and nectarine fruit epidermis by culture filtrates of phytopathogenic fungi
}

\author{
C Nguyen-The ${ }^{1}$, A Chamel 2* \\ 1 INRA, Station de Technologie des Produits Végétaux, Domaine St-Paul, 84140 Montfavet; \\ 2 CEADirection des Sciences du Vivant, DBMS/Laboratoire de Physiologie Cellulaire Végétale ** \\ CENG $85 X, 38041$ Grenoble Cédex, France
}

(Received 23 April 1990; accepted 3 December 1990)

\begin{abstract}
Summary - In vitro degradation of isolated cuticular membranes and in vivo degradation of the epidermis of nectarine fruit by Rhizopus stolonifer and Monilia laxa were investigated. Increases in the permeability of cuticular membranes to ${ }^{86} \mathrm{Rb}$ and of epidermis to ${ }^{45} \mathrm{Ca}$ were used as a measure of degradation. An isolate of Fusarium solani $\mathrm{f} \mathrm{sp}$ pisi, which produced a large amount of cutinase, was used as a reference. Culture filtrates of $R$ stolonifer and $M$ laxa did not change cuticular membrane permeability. Conversely, both fungi caused a marked deterioration in the epidermis of nectarine fruit, probably caused by pectinolytic enzymes. The reaction is thought to probably take place in the cuticular microcracks present on the nectarine fruit surface. Penetration of nectarine fruit epidermis by $M$ laxa and $R$ stolonifer does not apparently involve cutinolytic enzymes.
\end{abstract}

Rhizopus stolonifer / Monilia laxa / Fusarium solani / isolated cuticle / cutinase

Résumé - Dégradation enzymatique de cuticules isolées de plantes et de l'épiderme de nectarines par des filtrats de culture de champignons phytopathogènes. Dans ce travail, la dégradation in vitro de membranes cuticulaires isolées et la dégradation in vivo de l'épiderme de nectarine par Rhizopus stolonifer et Monilia laxa ont été étudiées. Cette dégradation a été mesurée, d'une part par l'augmentation de la perméabilité de membranes cuticulaires $a u{ }^{86} R b$, et d'autre part par l'augmentation de la perméabilité de l'épiderme au ${ }^{45} \mathrm{Ca}$. Un isolat de Fusarium solani $f s p$ pisi, a servi de référence. Le traitement de cuticules isolées avec des filtrats de culture de ce champignon augmente la perméabilité cuticulaire au ${ }^{86} \mathrm{Rb}$ (figs 2 et 3); par contre, le transfert du ${ }^{86} \mathrm{Rb}$ après traitement des cuticules par des surnageants de culture de $\mathrm{R}$ stolonifer et $\mathrm{M}$ laxa, dans des conditions comparables d'activité enzymatique, n'est pas modifié (fig 3). Les filtrats de culture de Fusarium solani $f$ sp pisi causent aussi une perte de poids de cuticules isolées décirées confirmant ainsi la présence de cutinase dans les solutions de culture testées. Les 2 champignons, $\mathrm{R}$ stolonifer et $\mathrm{M}$ laxa provoquent une nette dégradation de l'épiderme de nectarine, visible après coloration au bleu de méthylène, qui se traduit par une pénétration plus élevée $d u{ }^{45} \mathrm{Ca}$ dans les fruits (fig 4). Le traitement avec un filtrat de culture de Fusarium solani $f s p$ pisi qui ne présente pas d'activité pectinolytique, est sans effet. Les enzymes pectinolytiques produites par $\mathrm{R}$ stolonifer et $\mathrm{M}$ laxa sont vraisemblablement à l'origine de l'altération observée avec ces champignons, qui survient sans doute au niveau de microfissures cuticulaires présentes à la surface des nectarines. La pénétration de l'épiderme de nectarines par $\mathrm{M}$ laxa et $\mathrm{R}$ stolonifer n'implique probablement pas l'intervention d'enzymes cutinolytiques.

Rhizopus stolonifer / Monilia laxa / Fusarium solani / cuticule isolée / cutinase

\footnotetext{
* Correspondence and reprints

** Address of the establishment where this study was carried out
} 


\section{INTRODUCTION}

Monilia laxa (Aderh and Ruhl) Honey and Rhizopus stolonifer (Ehrenb ex Fr) Lind are the principal fungal pathogens in Europe of peach and nectarine during storage (Anderson, 1925; Byrde and Willetts, 1977; Bompeix et al, 1979). Although infection of fruit by both fungi frequently occurs through wounds, direct penetration of germinated conidia of $M$ laxa has been demonstrated (Wade, 1956; Hall, 1971). Direct penetration of the plant cuticle by fungal pathogens (Rijkenberg et al, 1980; Dickman et al, 1982, 1983; Kolattukudy and Koller, 1983) or bacterial pathogens (Bashan et al, 1985) requires the production of cutin-degrading enzymes (cutinases). Microcracks on the surface of nectarine fruit (Fogle and Faust, 1975, 1976) might provide alternative sites for fungal penetration. From electron microscopic observations, microcracks can be the main sites of penetration for the mycelium of $M$ laxa and $R$ stolonifer (Nguyen-The et al, 1989). The biochemical composition and the presence or absence of cutinized material associated with these microcracks has not been determined. Therefore it seems important to investigate whether or not cuticular degradation is involved during the penetration processes of $M$ laxa and $R$ stolonifer in nectarine fruit. An isolate of Fusarium solani $\mathrm{f} \mathrm{sp}$ pisi which produces a large amount of cutinase (Baker et al, 1982; Kolattukudy, 1985) was used as a reference. Increases in the permeability of nectarine fruit epidermis and of isolated pear cuticular membranes were used to determine the involvement of extracellular enzymes of both fungi upon cuticular penetration.

\section{MATERIALS AND METHODS}

\section{Fungal cultures}

Strains of $M$ laxa and $R$ stolonifer were isolated from decaying fruits, as for previous investigations (Nguyen-The et al, 1985a, b; 1989). The isolate of $F$ solani $\mathrm{fp}$ pisi was purchased from the Centraalbureau voor Schimmelcultures (Baarn, The Netherlands) isolate CBS.188.35.

\section{Fruits}

Nectarine fruits of the Armking cultivar were grown in experimental orchards (INRA, Alenya, France). Fruits were harvested at the stage of commercial maturity.

\section{Isolated cuticular disks}

Cuticular disks ( $1 \mathrm{~cm}$ diameter) were isolated by enzymatic maceration ( $2 \%$ pectinase; $0.2 \%$ cellulase, Sigma USA) from fully developed pear leaves (Pyrus communis L, cultivar Passe Crassane) and from the skin of mature tomato fruit (Lypersicon esculentum Mill) according to the procedure described in Chamel and Bougie (1977). The pear leaf cuticular disks used were obtained from the astomatous upper surface; the absence of any visible hole was checked using a light microscope $(x+50)$. This material has already been used widely as a model in cuticular permeability studies (Chamel, 1986).

\section{Culture solutions}

Two liquid culture media were used for the production of cutinase: a V8 medium supplemented with $0.5 \%(\mathrm{w} /$ v) of cutin powder (Baker et al, 1982) and a synthetic medium (Salinas et al, 1986: $10 \mathrm{~g} \mathrm{KNO}_{3} ; 5 \mathrm{~g} \mathrm{KH}_{2}$ $\mathrm{PO}_{4} ; 0.25 \mathrm{~g} \mathrm{Mg} \mathrm{SO}_{4}, 7 \mathrm{H}_{2} \mathrm{O} ; 0.4 \mathrm{mg} \mathrm{FeCl} 3 ; 3.6 \mathrm{~g}$ glucose; $250 \mathrm{mg}$ cutin powder; $\mathrm{H}_{2} \mathrm{O}$ dist 1 l). To obtain the cutin powder, tomato fruits were dipped in boiling water and hand-peeled. The skins were twice macerated over a $1-d$ period in a mixture of $1 \%$ pectinase + $1 \%$ cellulase (Fluka, Switzerland) diluted in a 0.05 mol..$^{-1} \mathrm{pH} 4.8$ sodium acetate buffer. The skins were rinsed in distilled water, then in methanol. The cuticular membranes obtained were dewaxed in a mixture of chloroform/methanol (1/1) for $1 \mathrm{~h}$ and in chloroform twice for $1 \mathrm{~h}$. The chloroform was decanted and the membranes were ground in methanol, firstly with an Omni-mixer (Sorvall, Newtown, USA) and secondly with a Polytron homogeniser (Kinematica, Switzerland) to obtain a very fine powder. The methanol was decanted and the powder dewaxed in an identical manner to that used for the cuticular membranes. About $0.75 \mathrm{~g}$ of cutin powder were obtained from $2 \mathrm{~kg}$ of tomato fruits. The production of pectinolytic enzymes was performed in a pectin liquid medium, as described previously (Nguyen-The et al, 1984).

Fungi were grown at $25^{\circ} \mathrm{C}$ on a shaker in $30 \mathrm{ml}$ of culture solution placed in an Erlenmeyer flask. The inoculum consisted of spores of $R$ stolonifer $\left(\approx 10^{5}\right.$ spores/flask) or 10 disks ( $4 \mathrm{~mm}$ diameter) of mycelium of $M$ laxa or $F$ solani $\mathrm{sp}$ pisi cut from a culture of the fungus on potato dextrose agar. After $5 \mathrm{~d}$ ( $R$ stolonifer grown on pectin medium), 1 wk ( $M$ laxa grown on pectin medium), or more generally 3 wk ( $R$ stolonifer, $M$ laxa, $F$ solanif sp pisi grown on $\mathrm{V} 8+$ cutin solution or on synthetic medium), the respective liquid cultures were centrifuged for $20 \mathrm{~min}$ at $25000 \mathrm{~g}$ and the filtrates stored at $-20^{\circ} \mathrm{C}$ before use.

\section{Enzyme assays}

Cutinase was assayed by the degradation of fatty acid esters using para-nitrophenyl-butyrate (PNPB) (Sig- 
ma, USA) as the substrate. Release of p-nitrophenol from para-nitrophenol ester of butyric acid is a rapid method to assay cutinase activity, but it is not specific since many fatty acid esterases do not hydrolyse cutin polymers (Kolattukudy, 1985). The production of phenol was detected at $405 \mathrm{~nm}$ with a DMS-100 (Varian, USA) spectrophotometer. Reactions were performed at $30^{\circ} \mathrm{C}$ in a Tris/ $\mathrm{HCl} 0.1 \mathrm{M} \mathrm{pH} 8$ buffer with $0.01 \%$ Triton X-100 (Fluka, Switzerland) $0.1 \%$ PNPB using $100 \mu \mathrm{l}$ culture filtrate in $2.5 \mathrm{ml}$ of the substrate solution. Activity was expressed in absorbance units at $405 \mathrm{~nm}$ per min (Au/min).

Pectinolytic activity was measured by a viscosimetric method or by the release of a reducing group and routinely detected in culture filtrates with an agar diffusion assay (Hornewer et al, 1987). Assays were conducted at $\mathrm{pH} 5$ (sodium acetate buffer), $\mathrm{pH} 7$ (sodium phosphate buffer) and $\mathrm{pH} 8$ (Tris/ $\mathrm{HCl}$ buffer) in $0.05-\mathrm{mol}^{-1^{-1}}$ solutions.

\section{Estimation of the permeability of isolated cuticular membranes}

The diffusion of ${ }^{86} \mathrm{Rb}$ (a $185 \mathrm{kBq} / \mathrm{ml}$ solution which contained $0.1 \mathrm{mmol} . \mathrm{I}^{-1} \mathrm{Cl}-$ ion as $\mathrm{KCl}+\mathrm{RbCl}$, in a 10 mmol. I $^{-1} \mathrm{pH} 8$ Hepes buffer) was measured by the following procedure. A pear cuticular disk was attached to the end of a thick-walled glass tube $(7 \mathrm{~mm}$ inner diameter), dipped in a scintillation glass vial containing $10 \mathrm{ml}$ of the non radioactive "receiver" solution (Hepes buffer, $10 \mathrm{mmol} . \mathrm{I}^{-1} \mathrm{pH} \mathrm{8}$ ). The cuticular disk was attached as previously described (Chamel and Bougie, 1977; Chamel, 1980) using RTV 111 (silicone adhesive substance, Rhône-Poulenc), with its external side (ie waxy surface of the cuticle) facing the inner space of the tube. System imperviousness was checked by replacing the cuticular disk by a microscope slide (Chamel, 1980). The solution of ${ }^{86} \mathrm{Rb}$ ("donor" solution) was placed inside the glass tube $(0.5$ $\mathrm{ml}$ ), and the tube was fixed so that the "donor" and "receiver" solutions were kept at the same level during diffusion (fig 1). The permeability of the cuticular disk was measured by the amount of radioactivity detected

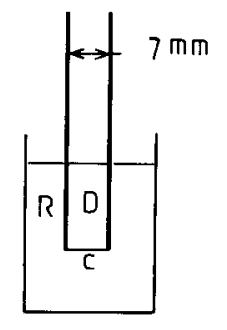

$$
\begin{aligned}
& \text { R:receiver } \\
& \text { D:donor } \\
& \text { C:cuticle }
\end{aligned}
$$

Fig 1. Apparatus for estimating the permeability of isolated cuticular membranes. $D=500 \mu \mathrm{l}$ of "donor" solution, which contained $185 \mathrm{kBq}$ of ${ }^{86} \mathrm{Rb}$ and $0.1 \mathrm{mmol} . \mathrm{I}^{-1}$ of $\mathrm{kCl}+\mathrm{RbCl}$ in a $10 \mathrm{mmol} .1^{-1} \mathrm{pH} 8$ Hepes buffer; $R=10 \mathrm{ml}$ of "receiver solution" wich consisted of $10 \mathrm{mmol}^{-1} \mathrm{I}^{-1} \mathrm{pH} 8$ Hepes buffer; $C=\mathrm{cu}$ ticular membrane isolated from pear leaf and stuck on the opening of a glass tube with waxy side upwards. in the "receiver" solution after $24 \mathrm{~h}$ at room temperature.

The degradation of cuticular disks by culture filtrates was assessed by the same method. Culture filtrates, diluted in $\mathrm{pH} 8$ Hepes buffer (final molarity 10 mmol. $1^{-}$) supplemented with $0.1 \%$ thimerosal (Prolabo, France) to prevent growth of microorganisms, were placed either inside the tube (to attack the waxy side of the cuticle) or both in the tube and in the glass vial (to attack both sides of the cuticle). After a $24 \mathrm{~h}$ incubation at room temperature, the cuticular membrane was rinsed several times with distilled water. Diffusion of ${ }^{86} \mathrm{Rb}$ through the isolated cuticular membrane was measured before and after the treatment with culture filtrate and the results are presented by the ratio $\mathrm{R}=$ diffusion after/diffusion before. In the case of low fatty esterase activity, the 24-h treatment was repeated 3 times with freshly thawed culture filtrate.

\section{In situ degradation of nectarine fruit epidermis}

A $20-\mu$ droplet of culture filtrate was deposited on the epidermis in the equatorial area of the nectarine fruit. Culture filtrate was either pure or diluted $(1: 1)$ in a $0.05-$ mol..$^{-1}$ sodium acetate buffer $\mathrm{pH} 4$ or a 0.05 mol.1-1 sodium phosphate buffer $\mathrm{pH}$ 7. The droplet evaporated within a few $h$ at room temperature and after $24 \mathrm{~h}$ the permeability of the epidermis was estimated by 2 methods:

- the fruit surface was stained with a water-ethanol solution of methylene blue (Prolabo, France) supplemented with Triton X-100;

- the penetration of ${ }^{45} \mathrm{Ca}$ inside the fruit was measured at the site previously treated with the culture filtrate. In this latter case, $20 \mu$ l of a ${ }^{45} \mathrm{Ca}$ solution $(925$ $\mathrm{kBq} / \mathrm{ml}, 20 \mathrm{mmol}^{-1} \mathrm{CaCl}_{2}$ in a $10 \mathrm{mmol}^{-1} \mathrm{pH} 5$ SADH buffer) were deposited on the fruit surface and after $24 \mathrm{~h}$ at room temperature, the radioactivity which remained on the fruit surface was washed twice with 2 $x 5 \mathrm{ml}$ Tween 20 solution $\left(0.1 \%\right.$ in a $10 \mathrm{mmol}^{-1} \mathrm{I}^{-1} \mathrm{pH} 5$ SADH buffer). As radioactivity counted in the second washing solution was only $4.5 \%$ of the radioactivity counted in the first, a third washing was considered unnecessary. Radioactivity which had diffused into the skin of the fruit was measured in a $1-\mathrm{cm}$ diameter disk peeled with a razor blade and dissolved in $1 \mathrm{ml}$ of Lumasolve (Lumac).

\section{Radioactivity measurements}

Radioactivity of ${ }^{86} \mathrm{Rb}$ was determined with a gamma counter apparatus (Intertechnique CG 4000, France). Counts were performed on 2-ml aliquots removed from the "receiver" solution and $20-\mu$ liquots removed from the "donor" solution. The latter were made up to $2 \mathrm{ml}$ with $\mathrm{H}_{2} \mathrm{O}$ so that all the samples had the same geometry in the counter. 
Radioactivity of ${ }^{45} \mathrm{Ca}$ was determined in $20-\mu \mathrm{l}$ aliquots of the $925 \mathrm{kBq} / \mathrm{ml}$ solution and in $100-\mu$ laliquots of the washing solution with a liquid scintillation counter (spectrometer Packard 4430). Aliquots were mixed with $10 \mathrm{ml}$ of Lumagel (Lumac). Skin samples dissolved in $1 \mathrm{ml}$ Lumasolve were counted in $9 \mathrm{ml}$ of $\mathrm{Lj}$ poluma (Lumac).

\section{Weight loss of cuticular material}

Dewaxed cuticular disks from tomato fruit were immersed for $24 \mathrm{~h}$ in the culture filtrate of $F$ solani $\mathrm{sp}$ pisi (grown in $\mathrm{V} 8$ + cutin solution) mixed with a 20 mmol. $1^{-1} \mathrm{pH} 8$ Hepes buffer (1:1). Disks in heated culture filtrate $\left(10 \mathrm{~min}, 100^{\circ} \mathrm{C}\right)$ were used as control. The disks $(\approx 10 \mathrm{mg}$ ) were placed in a scintillation vial with $3 \mathrm{ml}$ of solution. The experiment was performed on 5 vials in each case (active and inactive culture filtrate). The 10 disks of a vial were weighed before and after treatment.

\section{RESULTS}

\section{Permeability of isolated Pear leaf cuticles}

Production of fatty acid esterase by $F$ solani $\mathrm{fp}$ pisi and by $R$ stolonifer was higher in $\mathrm{V} 8+$ cutin solution than in the synthetic + cutin solution (table I). The isolate of $M$ laxa that we used in this investigation did not produce any detectable fatty acid esterase. The following experiments were conducted with culture filtrates of fungi grown on V8 + cutin solution, the fatty acid esterase activities of which are presented in table 1 .

Incubation of both sides of isolated cuticular membranes for $24 \mathrm{~h}$ with culture filtrates of $F$ so- lanif sp pisi led to an increase in the diffusion of ${ }^{86} \mathrm{Rb}$. The ratio of increased diffusion $(R)$ varied greatly among the different cuticular disks treated with the same culture filtrate (fig 2) with $R$ ranging from 1.3 to 5.2 . The experiment was carried out on 2 different cuticle samples and the individual variation was much lower in the second sample. It should be noted that treatment of the waxy side of the cuticular disk only did not cause
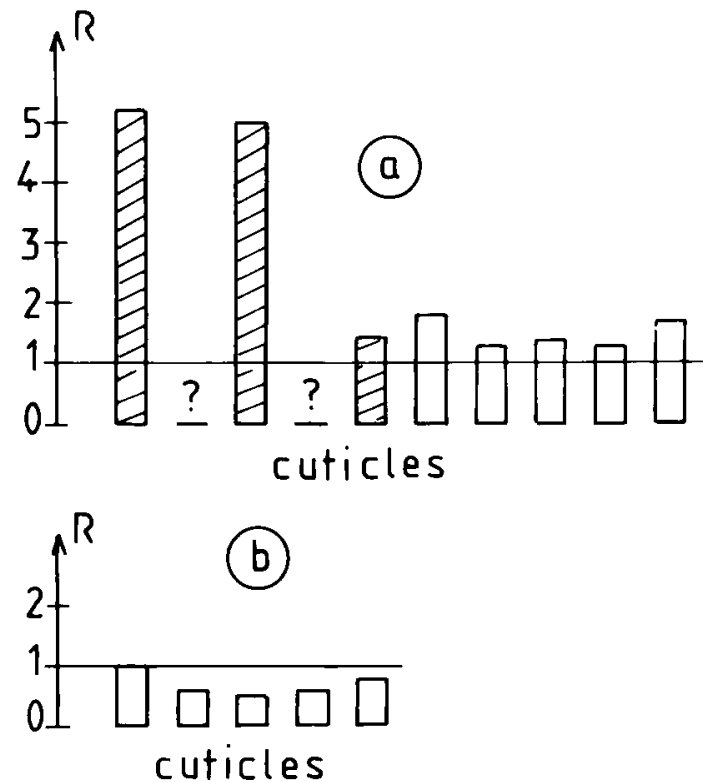

Fig 2. Variation in the diffusion of ${ }^{86} \mathrm{Rb}$ through isolated cuticular membranes before and after a 24-h treatment with the culture filtrate of $F$ solani $f \mathrm{sp}$ pisi. (a) Culture filtrate placed on both sides of the cuticular membrane; (b) culture filtrate placed on the waxy side of the cuticular membrane; $R$ = diffusion after treatment/diffusion before treatment; ? = fissures detected in the cuticular membrane at the end of the experiment. The experiment was performed on 2 samples of $5 \mathrm{cu}$ ticles each (ED and $\square$ ). $F$ solanif sp pisi was grown in V8 + cutin culture solution, and the filtrate was mixed ( 1 vol : 1 vol) with a $20 \mathrm{mmol}^{-1} \mathrm{pH} 8$ Hepes buffer.

Table I. Fatty acid esterase activities produced by $R$ stolonifer and $F$ solanif sp pisi grown in 2 culture solutions.

\begin{tabular}{|c|c|c|c|c|c|c|}
\hline \multirow{3}{*}{$\begin{array}{l}\text { Culture } \\
\text { Solutions }\end{array}$} & \multicolumn{3}{|c|}{ F solani $f$ sp pisi } & \multicolumn{3}{|c|}{ R stolonifer } \\
\hline & \multicolumn{3}{|c|}{$\rho H$} & & \multicolumn{2}{|c|}{$p H$} \\
\hline & 6 & 7 & 8 & 6 & 7 & 8 \\
\hline $\begin{array}{l}\text { Synthetic + cutin } \\
21 \mathrm{~d}\end{array}$ & NT & NT & $0.20 \pm 0.05$ & NT & NT & 0 \\
\hline $\begin{array}{l}V 8+\text { cutin } \\
21 d\end{array}$ & 0 & $0.50 \pm 0.125$ & $0.50 \pm 0.125$ & 0 & $0.025 \pm 0.006$ & $0.025 \pm 0.006$ \\
\hline
\end{tabular}

Enzymatic activities were measured by the degradation of para-phenylbutyrate and expressed in $A$ units at $405 \mathrm{~nm} / \mathrm{min}$. Each measurement was performed on combined filtrates from 3 flasks, each containing $30 \mathrm{ml}$ of culture filtrate; \pm standard deviation. NT = not tested. 
any increase in the diffusion of $86 \mathrm{Rb}$ ( $R$ lower than 1). An increase in $86 \mathrm{Rb}$ diffusion was still noticeable when the isolated cuticular disks were incubated with $F$ solanif $\mathrm{sp}$ pisi culture filtrate diluted in distilled water $(1 / 5,1 / 10,1 / 20$; fig 3$)$. The 24-h treatment was repeated 3 times before the second diffusion of $86 \mathrm{Rb}$. On the contrary however, although the $1 / 20$ dilution of $F$ solani $\mathrm{sp}$ pisi culture filtrate and $R$ stolonifer culture filtrate (grown on V8 + cutin solution) contained similar fatty acid esterase activity (table I), the latter had no significant effect upon the permeability of cuticular disks (compared to a control).

\section{Weight of dewaxed tomato cuticles}

Compared to the increase in permeability of pear cuticular disks, the culture filtrate of $F$ solani $\mathrm{sp}$ pisi (grown on V8 + cutin) caused a significant loss of weight in dewaxed cuticular membranes (table II). This confirms the presence of cutinase in the culture solutions tested.

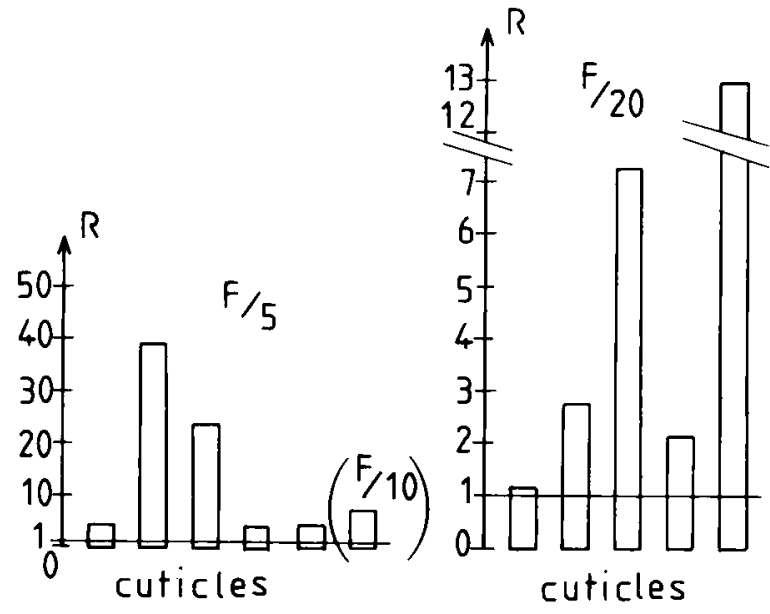

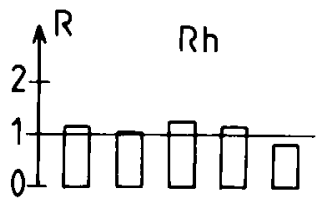

cuticles

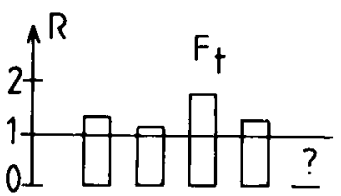

cuticles
Fig 3. Variations in the diffusion of ${ }^{86} \mathrm{Rb}$ through isolated cuticular membranes before and after treatment with fungal culture filtrate. The treatment consisted of 3 successive 24-h incubations with the culture filtrate. $F / 5, F / 10, F / 20=$ respectively $1 / 5,1 / 10,1 / 20$ water dilutions of $F$ solani $\mathrm{sp}$ pisi culture filtrate; $\mathrm{Ft}$ : culture filtrate of $F$ solani $\mathrm{fsp}$ pisi heated $10 \mathrm{~min}$ at $100^{\circ} \mathrm{C} ; \mathrm{Rh}=$ culture filtrate of $R$ stolonifer, $\mathrm{R}$ and ? $=$ see figure 2 . Rh and F/20 contained the same fatty acid esterase activity. Fungi were grown in V8 + cutin culture solution and culture filtrates (pure or diluted) were mixed with 100 mmol. ${ }^{1-1} \mathrm{pH} 8$ Hepes buffer ( 1 vol buffer: 9 vol culture filtrate). Radioactivity of the donor solution was $123809 \pm 2988 \mathrm{cpm}$ and the amount of radioactivity which diffused into the receiver before treatment never exceeded $10 \%$ of this value.
Table II. Weight loss of dewaxed, cuticular membranes isolated from tomato fruit and immersed during $24 \mathrm{~h}$ in culture filtrate of $F$ solanif sp pisi.

\begin{tabular}{lcc}
\hline & $F$ & $F t$ \\
\hline & & \\
W1 $(\mathrm{mg})$ & $10.62 \pm 0.54$ & $10.58 \pm 1.04$ \\
W2 $(\mathrm{mg})$ & $9.98 \pm 0.85$ & $10.35 \pm 0.98$ \\
$W_{1}-\mathrm{W}_{2}(\mathrm{mg})$ & $0.89 \pm 0.45$ & $0.23 \pm 0.08$ \\
$W_{1}-\mathrm{W}_{2} \mathrm{~W}_{1}(\%)$ & $8.2 \pm 4.0$ & $2.2 \pm 0.7$
\end{tabular}

W1: dry weight of 10 disks of cuticular membranes before treatment. W2: dry-weight after treatment. F: treatment with active culture filtrate; Ft: treatment with heated culture filtrate $\left(10 \mathrm{~min}, 100^{\circ} \mathrm{C}\right)$. Each value is the mean of 5 measures \pm standard deviation.

\section{Degradation of nectarine fruit epidermis}

Culture filtrate of $R$ stolonifer grown on a pectin medium deposited on the surface of nectarine fruit caused a marked alteration after $24 \mathrm{~h}$ at room temperature. It could be visualized by staining the surface with methylene blue: after rinsing the dye with tap water, a network of bluecoloured cracks remained. No such alteration occurred when boiled $\left(10 \mathrm{~min}, 100^{\circ} \mathrm{C}\right)$ filtrate was deposited on the fruit, but it could still be observed when culture filtrate was mixed with 0.1 mol. I $^{-1} \mathrm{pH} 4$ acetate buffer or $\mathrm{pH} 7$ phosphate buffer (1:1). Culture filtrate of $M$ laxa grown in the same solution induced a similar alteration, but in a weaker and less reliable manner: alteration occurred in $80 \%$ of the fruits treated with $R$ stolonifer and $40 \%$ of those treated with $M$ laxa. The presence of pectinolytic enzymes in the culture filtrate was checked by an agar diffusion assay and $M$ laxa culture filtrate contained only $5 \%$ of the enzymatic activity in the $R$ stolonifer culture filtrate.

Absorption of ${ }^{45} \mathrm{Ca}$ by the surface of nectarine fruit was higher in fruits previously treated with culture filtrate of $R$ stolonifer (grown on pectin medium) than with fruits treated with the same culture filtrate heated $10 \mathrm{~min}$ at $100{ }^{\circ} \mathrm{C}$. This could be demonstrated both by the lesser amount of ${ }^{45} \mathrm{Ca}$ which remained on the fruit surface (ie ${ }^{45} \mathrm{Ca}$ washed with Tween 20 solutions) and by the higher amount detected in the skin (fig 4). The addition of the amounts of $45 \mathrm{Ca}$ measured in washing solution and in the skin represented $74.6 \% \pm 5.6$ of the total amount deposited on the fruit. Approximately $25 \%$ must have penetrated deeper into the mesocarp and 


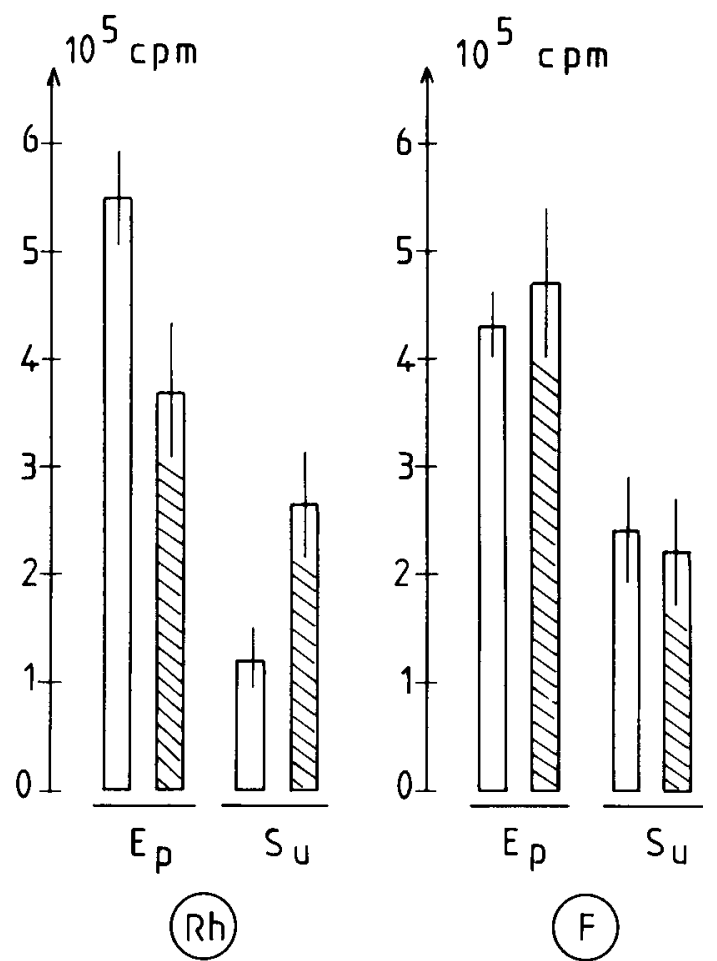

Fig 4. Penetration of ${ }^{45} \mathrm{Ca}$ inside nectarine fruits, the surface of which was previously treated with $20 \mu$ lof fungal culture filtrates during $24 \mathrm{~h}$. (Rh) culture supernatant of $R$ stolonifer grown on pectin medium $(\mathrm{pH} 4)$; $(F)$ culture supernatant of $F$ solani $f \mathrm{sp}$ pisi grown on $\mathrm{V} 8+$ cutin $(\mathrm{pH} 7)$. Su = radioactivity (cpm) which remained on the surface of fruit after $24 \mathrm{~h}$; $\mathrm{Ep}=$ radioactivity (cpm) measured in the skin; $\square$ = fruit treated with active culture supernatant (4 measures); 1010 fruit treated with boiled $\left(10 \mathrm{~min}, 100^{\circ} \mathrm{C}\right)$ culture supernatant $(3$ measures); П= standard deviation. The ${ }^{45} \mathrm{Ca}$ solution $(20 \mu \mathrm{l}) \mathrm{de}-$ posited on fruit consisted of a $925 \mathrm{kBq}, 20 \mathrm{mmol} . \mathrm{I}^{-1} \mathrm{CaCl}_{2}$ solution in a $10 \mathrm{mmol}^{-1} \mathrm{pH} 5 \mathrm{SADH}$ buffer and contained $942790 \pm 524 \mathrm{cpm}$.

was not counted in our experiment. Crude culture filtrate was used $(\mathrm{pH} 4)$, the pectinolytic activity of which (8 nkatal/ml) was measured and characterized in a previous investigation (Hornewer et al, 1987). However, no fatty acid esterase could be detected in this pectin medium, either at $\mathrm{pH} 4,6,7$ or 8 . A similar experiment was conducted with crude culture filtrate of $F$ solani f sp pisi $(\mathrm{pH} 7)$ grown on V8 + cutin medium, the fatty acid esterase activity of which is presented in table I. No significant effect on the penetration of ${ }^{45} \mathrm{Ca}$ could be noticed (fig 4). It should be noted that no pectinolytic activity could be detected in this culture filtrate, at $\mathrm{pH} 5, \mathrm{pH} 7$, or $\mathrm{pH} 8$.

\section{DISCUSSION}

In vitro, in a culture solution which contained cutin, $F$ solanif sp pisi and to a lesser extent $R$ stolonifer, produced some fatty acid esterases.
When convenient dilutions of these culture filtrates were tested, so as to assess the same fatty acid esterase activity in both, $F$ solani $\mathrm{fp}$ pisi caused a marked increase in the permeability of isolated cuticular membranes, whereas $R$ stolonifer did not. The considerable variability observed within the same species has already been reported in several studies related to cuticular penetration (Chamel, 1980; 1986). The variations are attributed to heterogeneity of the physicochemical structure of the cuticle. Baker et al (1982) have demonstrated that cutinases purified from a culture solution of $F$ solani $\mathrm{sp}$ pisi increased the diffusion of glucose and proteins through isolated cuticular disks. The similar results we obtained with a culture filtrate of our isolate of $F$ solanif $\mathrm{sp}$ pisi was probably linked to the presence of a cutinase. The culture filtrate of $R$ stolonifer did not increase the permeability of isolated cuticular membranes; the fatty acid esterase produced by the fungus is therefore presumably not a cutinase.

Our results are not sufficient to enable us to state that $R$ stolonifer could not produce any cutinase, since:

- only 2 culture media were tested. It might be advisable to confirm the results of the present investigation by using other culture media without a carbon source (like glucose) which could repress the cutinase production. The effect of shaking of the culture should also be considered. Lastly, the permeability assay with isolated cuticles should be tested at $\mathrm{pH}$ values above 8;

- the technique we used to detect cutinase may not be as sensitive as conventional methods with radiolabelled cutin powder (Kolattukudy, 1985; Salinas et al, 1986). Nevertheless, this provides a good argument for considering that cuticle degradation is not of great importance in the infection of fruit by $R$ stolonifer, contrary to $F$ solani $f$ $\mathrm{sp}$ pisi (Koller et al, 1982). This assumption is supported by the fact that a culture filtrate of $R$ stolonifer (grown on pectin medium) caused a marked increase in the permeability of nectarine fruit epidermis, whereas it did not contain cutinase. The radioactivity of ${ }^{45} \mathrm{Ca}$ measured in the skin is mainly attributable to $\mathrm{Ca}$ ions that have penetrated as the greatest fraction of $\mathrm{Ca}$ retained by the cuticle (as free ion and exchangeable) was removed by rinsing with an acid solution (10 mmol. ${ }^{-1}$ buffer, $\mathrm{pH} 5$ ), as previously shown elsewhere in the case of isolated apple fruit cuticles (Chamel, 1983). Moreover, it has been shown that $\mathrm{Ca}$ can penetrate into apple and tomato fruit directly across the fruit cuticle (Chamel, 1989). 
Whatever the effect, the results indicate a modification of the fruit surface following its treatment by the culture filtrate of $R$ stolonifer. The results obtained with $M$ laxa are less consistent, since fatty acid esterase production was not detectable and degradation of nectarine fruit surface (revealed by the staining with methylene blue) was not constant. Nevertheless, these results also suggest that cuticle degradation is not involved in the infection of nectarine by M laxa.

Pectinolytic enzymes play an important role in the pathogenicity of $M$ laxa and $R$ stolonifer (Byrde and Willetts, 1977, Nguyen-The et al, $1985 \mathrm{a}, \mathrm{b})$, especially during post-penetration processes. From the present investigation, it can be assumed that these enzymes are also important during the penetration of both fungi in nectarine fruit. This would imply that non-cutinized (or poorly cutinized) areas are present on the surface of nectarine fruit. Microcracks that we observed on the cuticle of nectarine fruit (Nguyen-The et al, 1989) are possibly the sites of degradation of the epidermis by $R$ stolonifer and $M$ laxa culture filtrates. Penetration of fungal pathogens in fruits through microcracks has already been observed in the case of apple and Phytophthora cactorum (Mourichon and Bompeix, 1979) or in the case of grape and Botrytis cinerea (Bessis, 1972; Pucheu-Plante and Mercier, 1983), although a direct penetration of tomato fruit which involved the degradation of cuticle has been demonstrated with $B$ cinerea (Rijkenberg et al, 1980). Research is in progress to investigate the fine structure of cuticular microcracks on nectarine fruit.

\section{ACKNOWLEDGMENT}

This work was supported by a grant from the Institut National de la Recherche Agronomique.

\section{REFERENCES}

Anderson HM (1925) Rhizopus rot of peaches. Phytopathology 15, 122-124

Baker CJ, McCormick SL, Bateman DF (1982) Effects of purified cutin esterase upon the permeability and mechanical strength of cutin membranes. Phytopathology $72,420-423$

Bashan $Y$, Okon $Y$, Henis $Y$ (1985) Detection of cutinases and pectin enzymes during infection of tomato by Pseudomonas syringae pv tomato. Phytopathology 75, 940-945

Bessis R (1972) Étude en microscopie électronique à balayage des rapports entre l'hôte et le parasite dans le cas de la pourriture grise. Cr Acad Sci Paris Sér D 274, 2991-2994

Bompeix G, Coeffic M, Greffier P (1979) Lutte contre les pourritures des pêches à Monilia spp Botrytis sp et Rhizopus sp. Fruits 34, 423-430

Byrde RJW, Willetts HY (1977) The Brown Rot Fungi of Fruit, Their Biology and Control. Pergamon Press, N Y, pp 171

Chamel A (1980) Pénétration du cuivre à travers des cuticules isolées de feuilles de poirier. Physiol Vég $18,313-323$

Chamel A (1983) Utilization of isolated apple fruit cuticles to study the behaviour of calcium supplied directly to the fruit. Acta Hortic 138, 23-34

Chamel A (1986) Foliar absorption of herbicides: study of the cuticular penetration using isolated cuticles. Physiol Vég 24, 491-508

Chamel A (1989) Permeability characteristics of isolated "Golden Delicious" apple fruit cuticles with regard to calcium. J Am Soc Hortic Sci 114, 804-809

Chamel A, Bougie B (1977) Absorption foliaire du cuivre : étude de la fixation et de la pénétration cuticulaires. Physiol Vég 15, 679-693

Dickman MB, Patil SS, Kolattukudy PE (1982) Purification, characterisation and role in infection of an extracellular cutinolytic enzyme from Colletotricum gloeosporioides on Carica papaya. Physiol Plant Pathol 20, 333-347

Dickman MB, Patil SS, Kolattukudy PE (1983) Effects of organo-phosphorus pesticides on cutinase activity and infection of papayas by Colletotricum gloeosporioides. Phytopathology 73, 1209-1214

Fogle HW, Faust M (1975) Ultrastructure of nectarine fruit surface. J Am Soc Hortic Sci 100, 74-77

Fogle HW, Faust M (1976) Fruit growth and cracking in nectarines. J Am Soc Hortic Sci 101, 434-438

Hall R (1971) Pathogenicity of Monilia fructicola. II. Penetration of peach leaf and fruit. Phytopathol Z $72,281-290$

Hornewer A, Nguyen-The C, Nicolas J, Souty M (1987) Purification d'une polygalacturonase de Rhizopus stolonifer. Sci Aliments 7, 361-379

Kolattukudy PE (1985) Enzymatic penetration of the plant cuticle by fungal pathogens. Annu Rev Phytopathol 23, 223-250

Kolattukudy PE, Koller W (1983) Fungal penetration of defensive barriers of plants: In: Biochemical Plant Pathology (Callow JA, ed) John Wiley and Sons, Chichester, 79-100

Koller W, Allan CR, Kolattukudy PE (1982) Role of cutinase and cell wall degrading enzymes in infection of Pisum sativum by $\mathrm{F}$ solani $\mathrm{sp}$ pisi. Physiol Plant Pathol 20, 47-70

Mourichon X, Bompeix G (1979) Mise en évidence des voies de pénétration du Phytophthora cactorum ( $L$ et $C$ ) Schroeter dans les pommes "Golden Delicious". Étude réalisée en microscopie électronique à balayage. Fruits 34, 761-766

Nguyen-The C, Bertheau Y, Coléno A (1984) Études des isoenzymes de polygalacturonases, d'endo- 
glucanases de Rhizopus spp et Mucor spp et différenciation d'isolats dans le sud-est de la France. Can J Bot 62, 2670-2676

Nguyen-The C, Souty M, Breuils L (1985a) Dégradation des substances pectiques de pêche par Rhizopus stolonifer. II. Étude in vivo. Sci Aliments 5, 639652

Nguyen-The C, Souty M, Chambroy Y (1985b) Dégradation des substances pectiques de pêche par Rhizopus stolonifer. I. Rôle possible dans les interactions hôte-parasite. Sci Aliments 5, 447-463

Nguyen-The C, Hugueney R, Arnoux M (1989) Contribution à l'étude des voies de pénétration de parasites fongiques de nectarines, Monilia laxa et Rhizopus stolonifer. Agronomie 9, 271-276
Pucheu-Plante B, Mercier M (1983) Étude structurale de l'interrelation hôte-parasite entre le raisin et le champignon Botrytis cinerea : exemple de la pourriture noble en Sauternais. Can J Bot 61, 1785-1797

Salinas J, Warnaar F, Verhoeff K (1986) Production of cutin hydrolyzing enzymes by Botrytis cinerea in vivo. J Phytopathol 116, 299-307

Rijkenberg FGH, De Leeuw GTN, Verhoeff K (1980) Light and electron microscopy studies of the infection of tomato fruits by Botrytis cinerea. Can J Bot $58,1394-1404$

Wade GC (1956) Investigations on brown rot of apricots caused by Sclerotinia fructicola (Wint). Rehm. I. The occurrence of latent infection in fruit. Aust $J$ Agric Res 7, 504-515 